УДК 677.017.8

І.А.МАРТИРОСЯН

Одеська національна академія харчових технологій

О.В. ПАХОЛЮК

Луцький національний технічний університет

Б.Д. СЕМАК

Львівський торговельно-економічний університет

\title{
ДОСЛІДЖЕННЯ СВІТЛОСТІЙКОСТІ ПОФАРБУВАНЬ БАВОВНЯНОГО ТРИКОТАЖУ, ОБРОБЛЕНОГО НОВИМИ ТІОСУЛЬФОНАТНИМИ ПРЕПАРАТАМИ
}

\author{
И.А. МАРТИРОСЯН \\ Одесская национальная академия пищевых технологий \\ Е.В. ПАХОЛЮК \\ Луикий национальный технический університет \\ Б.Д. СЕМАК \\ Львовский торгово-экономический университет \\ ИССЛЕДОВАНИЕ СВЕТОСТОЙКОСТИ ОКРАСКИ ХЛОПКОВОГО \\ ТРИКОТАЖА, ОБРАБОТАННОГО НОВЫМИ \\ ТИОСУЛЬФОНАТНЫМИ ПРЕПАРАТАМИ
}

\author{
I.MARTIROSYAN \\ Odessa National Academy of Food Technologies \\ E. PAKHOLIUK \\ Lutsk national technical university \\ B. SEMAK \\ Lviv trade and economic university
}

\section{RESEARCH OF THE LIGHTFASTNESS OF THE COTTON JERSEY TREATED BY THE NEW THIOSULPHONATES PREPARATIONS}

\section{https://doi.org/10.36910/6775-2310-5283-2019-12-17}

Мета. Аналіз світлостійкості пофарбувань та субстрату білизняного бавовняного трикотажу обробленого антимікробними тіосульфонатними обробними препаратами ETC, MTC і АTC. Методика. При дослідженнях використовували передбачені діючими державними стандартами методи, які дозволяють визначити світлостійкість забарвлень (колірний тон, світлість, насиченість, загальний колірний контраст) та розривальні характеристики бавовняних білизняних трикотажних полотен, що досліджуються. Для оиінки світлостійкості пофарбувань, яке проводилось у лабораторії ДП «Хімтекст» (м. Херсон), використано спектрофотометр Premier Colorscan Colorlab (Spectro:5100) згідно з вимогами ДСТУ ГОСТ ІСО 105 - 701:2000 з використанням розрахункових формул системи CIELxaxbx.

Результати. Вивчено можливість та обгрунтована доцільність використання у вітчизняному текстильному та трикотажному виробництвах тіосульфонатних обробних 
препаратів ETC, МTC і АTC для антимікробного оброблення бавовняних білизняних трикотажних полотен літнього асортименту з метою їх ефективного захисту від біодеструкції целюлозоруйнуючими патогенними та трунтовими мікроорганізмами. Встановлено, щз в прочесі антимікробного оброблення бавовняних трикотажних полотен препаратами ЕTC, MTC $i$ ATC не спостерігається помітних змін їх механічних властивостей (розривальне навантаження), щуо може погіриити зносостійкість та гігієнічні показники названих полотен в процесі експлуатації виробів із них. Не виявлено негативного впливу оброблення препаратами ЕTC, MTC $i$ ATC на зміну колірних характеристик (світлості, насиченості, колірного тону $і$ загального колірного контрасту) i світлостійкості пофарбувань досліджуваних трикотажних полотен кубовими барвниками. Основною перевагою тіосульфонатних обробних препаратів $\epsilon$ те, щуо їх використання гарантує одночасне досягнення на трикотажних бавовняних білизняних $i$ одягових полотнах високої атмосферостійкості без погіршення їх механічних властивостей.

Наукова новизна. В результаті проведених досліджень, встановлено, щзо тіосульфонатні антимікробні препарати ЕTC, МТC $і$ АTC здатні ефективно захищати бавовняні білизняні трикотажні полотна літнього асортименту від тривалої дії сонячної padiaųii.

Практична значимість. Встановлено, щуо обрані нами тіосульфонатні препарати ETC, MTC i ATC придатні не тільки для ефективного захисту від мікробіологічної деструкиії, але й від тривалої дї світлопогоди бавовняних трикотажних полотен літнього асортименту (робочого одягу, спортивної білизни).

Ключові слова: трикотажні полотна, кулірна гладь, антимікробні препарати, світлостійкість, світлостійкість субстрату, тіосульфонатні біоцидні препарати.

\section{Постановка проблеми у загальному вигляді та її зв'язок із} важливими науковими чи практичними завданнями. Як свідчить аналіз літературних даних [1-4], в останні роки в обробному текстильному виробництві йде постійний пошук більш досконалих і екологічно безпечних засобів для антимікробної обробки целюлозовмісних текстильних матеріалів і трикотажних полотен різного цільового призначення. Одним із напрямів цієї роботи є впровадження в целюлозне виробництво нових типів антимікробних обробних препаратів для надання одяговим бавовняно-поліефірним різнокомпонентним тканинам одночасно біостойкості, атмосферостійкості та екологічної безпечності. Найбільш затребуваним $\epsilon$ створення подібних матеріалів для виготовлення виробів білизняного асортименту, які безпосередньо контактують зі шкірою, безпечних для здоров'я людини i навколишнього середовища. Вироби 3 таких матеріалів можуть бути використані як в побуті, так i в медичних установах, в харчовій промисловості, в поїздах далекого прямування, в армії і т.д.

Розробці різних методів отримання та вивчення властивостей матеріалів 3 антисептичними властивостями приділяється значна увага в усьому світі. Однак, незважаючи на великий обсяг робіт в цій області багато питань ще $є$ 
далекі від їх вирішення. Зокрема, актуальним завданням $\epsilon$ створення екологічно чистих текстильних матеріалів i трикотажних полотен 3 антимікробними властивостями, що зберігаються при вологих обробках, праннях, світловому впливі, що необхідно при використанні виробів білизняного асортименту в реальних умовах. Не менш актуальні проблеми, пов'язані зі зниженням витрат на отримання таких матеріалів.

Як відомо, домінуючим чинником зношування трикотажних бавовняних білизняних і одягових полотен літнього асортименту являється тривала дія на них в умовах експлуатації світлопогоди. Причому під дією світлопогоди, як правило, швидше руйнується нанесений на ці тканини барвник. Тому для забезпечення рівномірного світлостаріння волокнистої основи і пофарбування названих тканин важливе значення має такий цілеспрямований відбір для їх фарбування барвників i обробних антимікробних препаратів, які б гарантували отримання не тільки потрібної гами кольорів забарвлень, ефективний захист текстилю від мікробіологічної деструкції, але й більш повне і ефективне використання потенційного ресурсу волокнистої основи тканин в умовах їх експлуатації.

Для обгрунтування можливості i доцільності використання у вітчизняному текстильному виробництві нових типів антимікробних тіосульфонатних препаратів (ЕТC, МТC, АТC), нами вивчено:

- $\quad$ вплив ЕТС, МТС та АТC на зміну світлостійкості волокнистої основи досліджуваних полотен і їх пофарбувань кубовими барвниками;

- $\quad$ вплив ЕTC, МТC та АTC на зміну механічних властивостей досліджуваних трикотажних полотен до і після 300 год. їх інсоляції.

Аналіз останніх досліджень, у яких започатковано вирішення проблеми. Проблема пошуку шляхів ефективного захисту текстилю від мікробіологічних пошкоджень завжди була і залишається актуальною. Це в повній мірі стосується і захисту бавовняного білизняного трикотажу, який безпосередньо контактує із тілом людини і є чутливим одночасно до дії целюлозоруйнуючих i патогенних видів мікроорганізмів. Для прикладу зупинимось на конкретному аналізі деяких літературних джерел, присвячених цій складній та різноплановій проблемі. Авторами роботи [2] розглянуто безпечність біостійкості текстилю як один із основних чинників захисту текстильної сировини і готової продукції в процесі їх зберігання, переробки та експлуатації (особливо це стосується целюлозовмісних текстильних матеріалів білизняного одягового та взуттєвого призначення). 
Підкреслюється, що біостійкість текстилю в останні роки відіграє ключову роль у формуванні асортименту та властивостей текстилю медичного призначення. В роботі [3] обгрунтована можливість та доцільність широкого використання для антимікробного оброблення i захисту текстилю від біодеструкції різноманітних видів обробних препаратів, які використовують для заключної обробки текстильних матеріалів і виробів. При цьому основна увага приділяється кремнійорганічним, фторорганічним та карбамольним препаратам. В роботі [4] основна увага приділяється характеристиці асортименту та властивостей нових типів біоцидних і фунгіцидних препаратів для ефективного захисту текстильних матеріалів (особливо одягового призначення від мікробіологічної деструкції).

Цілі статті. Дослідження світлостійкості пофарбувань та субстрату білизняного бавовняного трикотажу обробленого антимікробними тіосульфонатними обробними препаратами ЕТС, МТC i ATC. Дані тіосульфонатні обробні препарати є синтетичними аналогами природних фітонцидів (часнику Allium sativum, цибулі Allium сера, глибоководної морської водорості Echinocardium cordatum), які синтезовані на кафедрі технології біологічно активних сполук, фармації та біотехнології Національного університету «Львівська політехніка» [5].

Методи дослідження. Для вивчення світлостійкість пофарбувань i субстрату трикотажних полотен, була використана наступна методика інсоляції. Зразки полотен, які пофарбовані у чорний, червоний та зелений колір кубовими барвниками, до і після їх оброблення препаратами ЕТС, МТС i ATC, закріплялись на дерев'яні рамки і встановлювалися на спеціально підготовленій площадці у м. Одеса під кутом $45^{\circ}$ на південь. Інсоляцію тканин проводили тільки в сонячні дні (у серпні 2018 р.). Вологість повітря коливалось від 65 до $75 \%$, а температура від 25 до $35^{\circ} \mathrm{C}$. Загальна тривкість інсоляції 300 год. Після кожних 100 год. інсоляції зразки полотен відбирали для оцінки світлостійкості пофарбування і субстрату.

Про зміну світлостійкості пофарбувань та субстрату трикотажних полотен до і після їх оброблення тіосульфонатними препаратами судили таким чином:

- світлостійкість пофарбувань оцінювали за зміною колірного тону, насиченості, світлості та загального колірного контрасту;

- світлостійкість волокнистої основи досліджуваних полотен оцінювали за зміною їх розривального навантаження після 100, 200 і 300 годин сонячного опромінення. 
Для оцінки світлостійкості пофарбувань, яке проводилось у лабораторії ДП «Химтекст» (м. Херсон), використано спектрофотометр Premier Colorscan Colorlab (Spectro:5100) згідно з вимогами ДСТУ ГОСТ ICO 105 - 701:2000 3 використанням розрахункових формул системи CIEL $^{\mathrm{x}} \mathrm{a}^{\mathrm{x}} \mathrm{b}^{\mathrm{x}}$.

Розривальне навантаження досліджуваних полотен до i після їx сонячного опромінення оцінювали стандартним динамометричним методом.

Виклад основного матеріалу дослідження 3 повним обгрунтуванням отриманих наукових результатів. Об'єктом досліджень при вирішенні поставлених завдань служила бавовняна кулірна гладь білизняного призначення (табл. 1), отримана із бавовняної пряжі 56 текс (вар. 1) i бавовняної пряжі 52 текс (варіант 2 і 3).

Таблиця 1

Заправні дані кулірної гладі

\begin{tabular}{|c|c|c|c|c|c|c|c|}
\hline \multirow{2}{*}{ 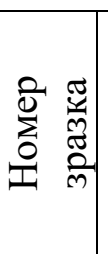 } & \multirow{2}{*}{$\begin{array}{c}\text { Волокнистий } \\
\text { склад, \% } \\
\text { та вид } \\
\text { переплетення }\end{array}$} & \multirow{2}{*}{ 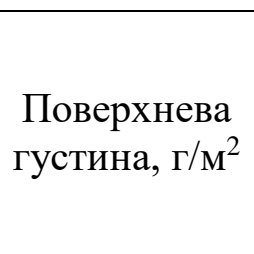 } & \multirow{2}{*}{$\begin{array}{c}\text { Товщина } \\
\text { полотна } \\
\text { М, мм }\end{array}$} & \multicolumn{2}{|c|}{$\begin{array}{c}\text { Щільність - } \\
\text { число пряжі на } 10 \\
\text { см }\end{array}$} & \multirow{2}{*}{$\begin{array}{c}\text { Лінійна } \\
\text { густина, } \\
T, \text { текс }\end{array}$} & \multirow{2}{*}{$\begin{array}{c}\text { Вид i } \\
\text { марка } \\
\text { барвника }\end{array}$} \\
\hline & & & & $\begin{array}{c}\text { пет. } \\
\text { стовп. }\end{array}$ & $\begin{array}{c}\text { пет. } \\
\text { рядків }\end{array}$ & & \\
\hline 1 & $\begin{array}{c}\text { Бавовна } \\
\text { 100\% (чорний) } \\
\text { Кулірна гладь }\end{array}$ & 171,0 & 1,39 & 327,0 & 292,0 & 56,0 & $\begin{array}{l}\text { Кубовий } \\
\text { Akatint } \\
\text { Red } \\
\text { F5RK } \\
\text { (red 170) } \\
\text { Індія }\end{array}$ \\
\hline 2 & $\begin{array}{c}\text { Бавовна, } \\
100 \% \\
\text { (червоний) } \\
\text { Кулірна гладь }\end{array}$ & 150,0 & 1,13 & 316,0 & 250,0 & 52,0 & $\begin{array}{c}\text { Кубовий } \\
\text { Akatint } \\
\text { Phthalo } \\
\text { Green } 7 \\
\text { Індія } \\
\end{array}$ \\
\hline 3 & $\begin{array}{c}\text { Бавовна, } \\
100 \% \\
\text { (зелений) } \\
\text { Кулірна гладь }\end{array}$ & 150,0 & 1,15 & 318,0 & 251,0 & 52,0 & $\begin{array}{c}\text { Кубовий } \\
\text { Китай }\end{array}$ \\
\hline
\end{tabular}

Результати досліджень впливу тривалості сонячного опромінення (100, 200 і 300 год.) на зміну показників світлості, насиченості, колірного тону і загального колірного контрасту та міцності волокнистої основи, залежно від кольору пофарбувань (чорний, червоний, зелений) полотен до i після їх антимікробного оброблення препаратами ЕТС, МТC і АТC, наведені в таблицях 1-2 і на рис. 1-6. 
買

\begin{tabular}{|c|c|c|c|c|c|c|c|c|c|c|c|c|c|c|}
\hline \multirow{8}{*}{ 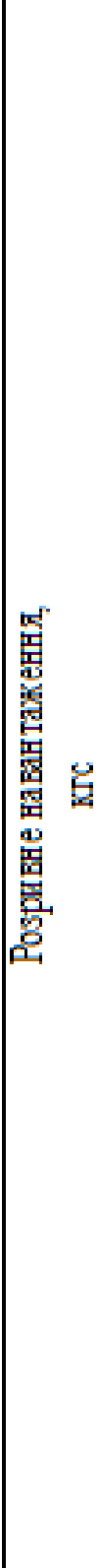 } & \multirow{2}{*}{$\begin{array}{c}\text { 몽 } \\
\text { 号 } \\
\text { 鸹 } \\
\text { 吕 }\end{array}$} & 刃 & 음 & r & 곡 & ' & $\stackrel{\circ}{\circ}$ & $\stackrel{\circ}{\circ}$ & శ్వి & $\sigma^{\circ}$ & त̂ & $\sigma^{\circ}$ & $\stackrel{0}{a}$ & ?. \\
\hline & & 由 冒 & 윰 & 음 & $\begin{array}{l}\infty \\
\text { o. } \\
\text { on }\end{array}$ & $\begin{array}{l}9 \\
\text { g. }\end{array}$ & $\begin{array}{l}\dot{q} \\
\text { 尔 }\end{array}$ & $\begin{array}{l}\infty \\
\text { 占 }\end{array}$ & 고 & $\stackrel{a}{\stackrel{a}{n}}$ & 它 & 응 & 哭 & 곡 \\
\hline & 몽 & 刃 䍚 & तु & 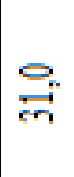 & 它 & 고 & g. & 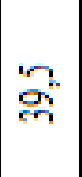 & 'ำ & 올 & g. & 을 & $\underset{\xi}{\rightleftarrows}$ & $\stackrel{\circ}{m}$ \\
\hline & 临 & 量 & m & 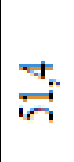 & on & 'g. & 음 & 票 & $\stackrel{\mathfrak{s}}{\infty}$ & $\stackrel{\infty}{i}$ & 영 & $\infty_{\infty}^{\infty}$ & $\therefore$ & $?$ \\
\hline & 몽 & 刃 总 & $\stackrel{\circ}{\circ}$ & 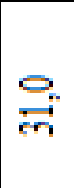 & 옴 & $\approx$ & $\underset{ }{\stackrel{y}{n}}$ & 욜. & 을 & 足 & ले & n & 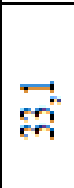 & $\overrightarrow{\mathrm{m}}$ \\
\hline & 苞 & 思鲁 & 융 & ๙2 & 음 & 응 & ๙ू. & త్ & 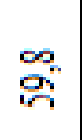 & 8 & 芦 & 욤 & 욤 & 요 \\
\hline & 嘪 & 嗄 & 잉 & $\underset{\text { 음 }}{\circ}$ & ष्ठ & 공 & 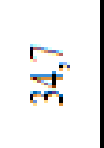 & $\overrightarrow{8}$ & m. & 용 & 윰 & 을 & 당 & "ै \\
\hline & 음 & 口 & 응 & 욤 & 용 & 讨 & $\approx$ & 6 & $\mathfrak{6}$ & 8 & ^ล & 6 & 8 & $\overrightarrow{0}$ \\
\hline & & $\begin{array}{l}\text { 临 } \\
\text { ' } \\
\text { 号 }\end{array}$ & 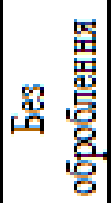 & 㞻 & 是 & 㫕 & 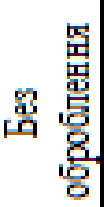 & $\underset{⿱ ㇒}{\stackrel{⿹}{凶}}$ & 是 & 夏 & 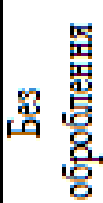 & 百 & 올 & 星 \\
\hline & 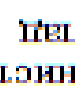 & $\begin{array}{l}\text { ID } \\
\text { rmog }\end{array}$ & $\% 0$ & 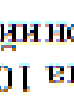 & Ioh & & $\% 0$ & 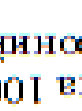 & 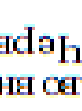 & & $\%$ & $\begin{array}{l}\text { йн } \\
0 \mathrm{O}\end{array}$ & & \\
\hline & QEEx & 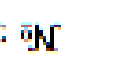 & & & $\rightarrow$ & & & & $\mathrm{d}$ & & & & $n$ & \\
\hline
\end{tabular}


У таблиці 2 наведені дані, що характеризують вплив тривалості сонячного опромінення (100, 200 і 300 год.) на зміну показників світлості, насиченості, колірного тону і загального колірного контрасту залежно від кольору пофарбувань (чорний, червоний, зелений) полотен до i після їх антимікробного оброблення препаратами ЕТС, МТC і АТС. При цьому встановлено:

- серед трьох колірних характеристик пофарбувань трикотажних полотен до і після оброблення препаратами ЕТС, МТС і АТС під дією тривалого сонячного опромінення (300год) найбільш суттєві зміни відбувались у показнику колірного тону;

- оброблення препаратами ЕТС, МТC і АТС досліджуваних полотен, як правило, призводить до суттєвого підвищення світлостійкості пофарбувань, при цьому кращий ефект досягається після оброблення полотен чорного i зеленого кольорів.

Таблиця 3

Вплив 300 годин сонячної радіації на зниження розривного навантаження трикотажних полотен, \%

\begin{tabular}{|c|c|c|c|c|}
\hline \multirow{2}{*}{$\begin{array}{c}\text { № } \\
\text { зразка }\end{array}$} & \multirow{2}{*}{$\begin{array}{c}\text { Волокнистий } \\
\text { склад }\end{array}$} & \multirow{2}{*}{$\begin{array}{c}\text { Вид } \\
\text { оброблення }\end{array}$} & \multicolumn{2}{|c|}{300 годин } \\
\hline & & & за шириною & за довжиною \\
\hline \multirow{4}{*}{1} & \multirow{4}{*}{$\begin{array}{c}\text { Бавовна } 100 \% \\
\text { чорний }\end{array}$} & Без оброблення & 31,3 & 29,3 \\
\hline & & ETC & 7,4 & 11,9 \\
\hline & & MTC & 10,0 & 18,3 \\
\hline & & ATC & 10,5 & 19,5 \\
\hline \multirow{4}{*}{2} & \multirow{4}{*}{$\begin{array}{c}\text { Бавовна } 100 \% \\
\text { Червоний }\end{array}$} & Без оброблення & 23,6 & 26,6 \\
\hline & & ETC & 15,7 & 11,2 \\
\hline & & MTC & 17,1 & 18,7 \\
\hline & & ATC & 13,5 & 15,1 \\
\hline \multirow{4}{*}{3} & \multirow{4}{*}{$\begin{array}{c}\text { Бавовна } 100 \% \\
\text { зелений }\end{array}$} & Без оброблення & 26,6 & 35,1 \\
\hline & & ETC & 12,2 & 15,1 \\
\hline & & MTC & 13,5 & 21,4 \\
\hline & & ATC & 13,3 & 23,7 \\
\hline
\end{tabular}

Таким чином, обрані нами тіосульфонатні препарати ЕTC, MTC і ATC придатні не тільки для ефективного захисту від мікробіологічної деструкції, але й від тривалої дії світлопогоди бавовняних трикотажних полотен літнього асортименту (особливо спортивної білизни).

Як відомо [6-8], у зношуванні бавовняного трикотажу літнього асортименту (спортивної білизни, сорочково-платтяних виробів) дія 
світлопогоди як і целюлозоруйнуючих мікроорганізмів, відіграє ключову роль. А тому важливо, щоб способи оброблення бавовняного білизняного трикотажу одночасно надавали високої світлостійкості та біостійкості.

Як видно з аналізу таблиць 2 і 3, обрані для оброблення бавовняного трикотажу препарати ЕTC, МТC і АTC суттєво гальмують процес атмосферної деструкції досліджуваних трикотажних полотен. Якщо після 300 годин опромінення розривальне навантаження полотен за шириною i довжиною до оброблення біоцидним препаратом ЕТС знижується відповідно на 31,3 і 29,3 \%, то після оброблення ЕТС це зниження становить 7,4 і 11,9\%. Подібна закономірність спостерігається і після оброблення препаратами МТС і АТС полотен вар. 1,2 і 3.

На рис. 1,2,3 показана залежність світлостійкості пофарбувань бавовняних трикотажних полотен вар. 1,2,3 від тривалості їх сонячного опромінення. Запропоновані відповідні моделі, які описують цю залежність. Окрім цього наведені діаграми, які показують зміни розривального навантаження названого полотна за шириною після 100, 200 і 300 годин його сонячного опромінення.

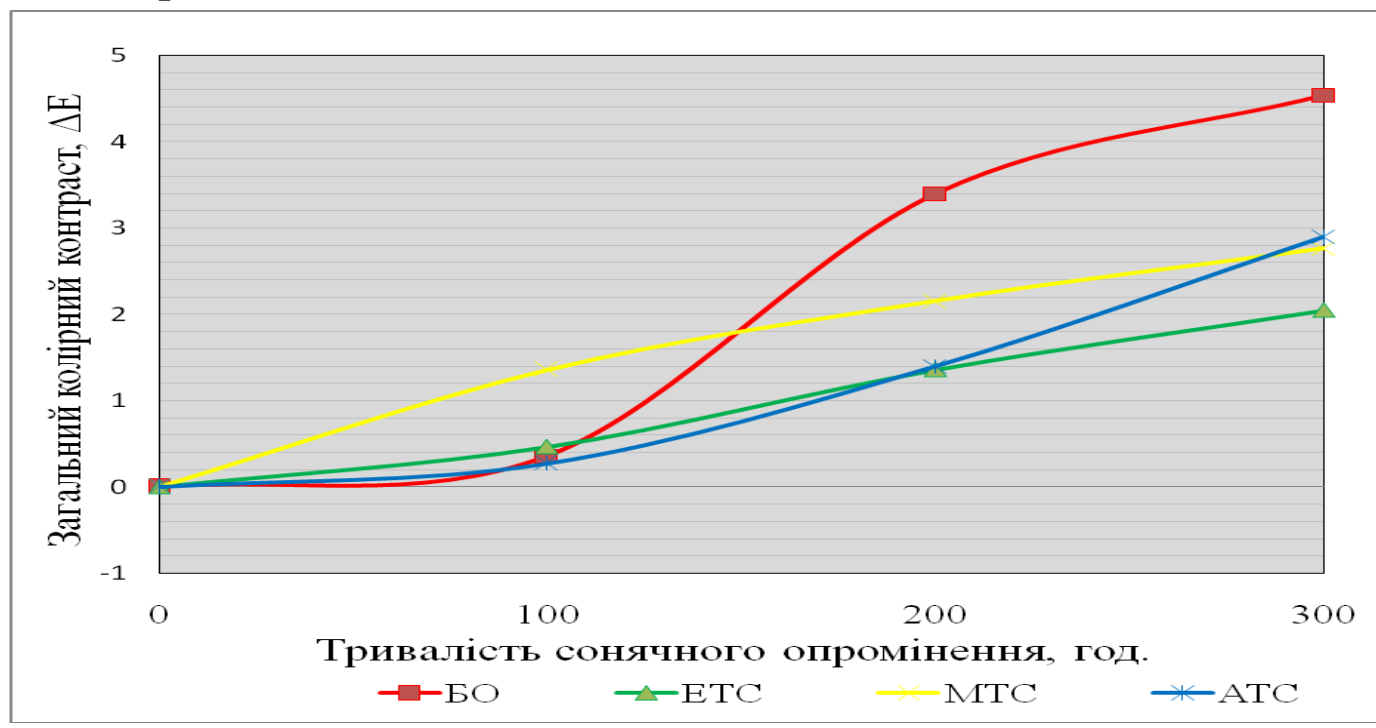

Рис. 1. Залежність світлостійкості забарвлень трикотажу (100\% бавовни - чорний) від тривалості сонячного опромінення

\begin{tabular}{|c|c|c|c|c|}
\hline $\begin{array}{c}\text { № } \\
\text { кривої }\end{array}$ & $\begin{array}{c}\text { Умовні } \\
\text { позначення }\end{array}$ & $\begin{array}{c}\text { Вид } \\
\text { оброблення }\end{array}$ & Рівняння & $\mathrm{R}^{2}$ \\
\hline 1 & & БО & $\mathrm{Y}=2 \mathrm{E}-0,5 \mathrm{x}^{2}+0,010 \mathrm{x}-0,229$ & 0,93 \\
\hline 2 & & $\mathrm{ETC}$ & $\mathrm{Y}=6 \mathrm{E}-0,6 \mathrm{x}^{2}+0,005 \mathrm{x}-0,031$ & 0,99 \\
\hline 3 & & $\mathrm{MTC}$ & $\mathrm{Y}=-2 \mathrm{E}-0,5 \mathrm{x}^{2}+0,014 \mathrm{x}-0,018$ & 0,998 \\
\hline 4 & & $\mathrm{ATC}$ & $\mathrm{Y}=3 \mathrm{E}-0,5 \mathrm{x}^{2}+0,000 \mathrm{x}-0,023$ & 0,997 \\
\hline
\end{tabular}




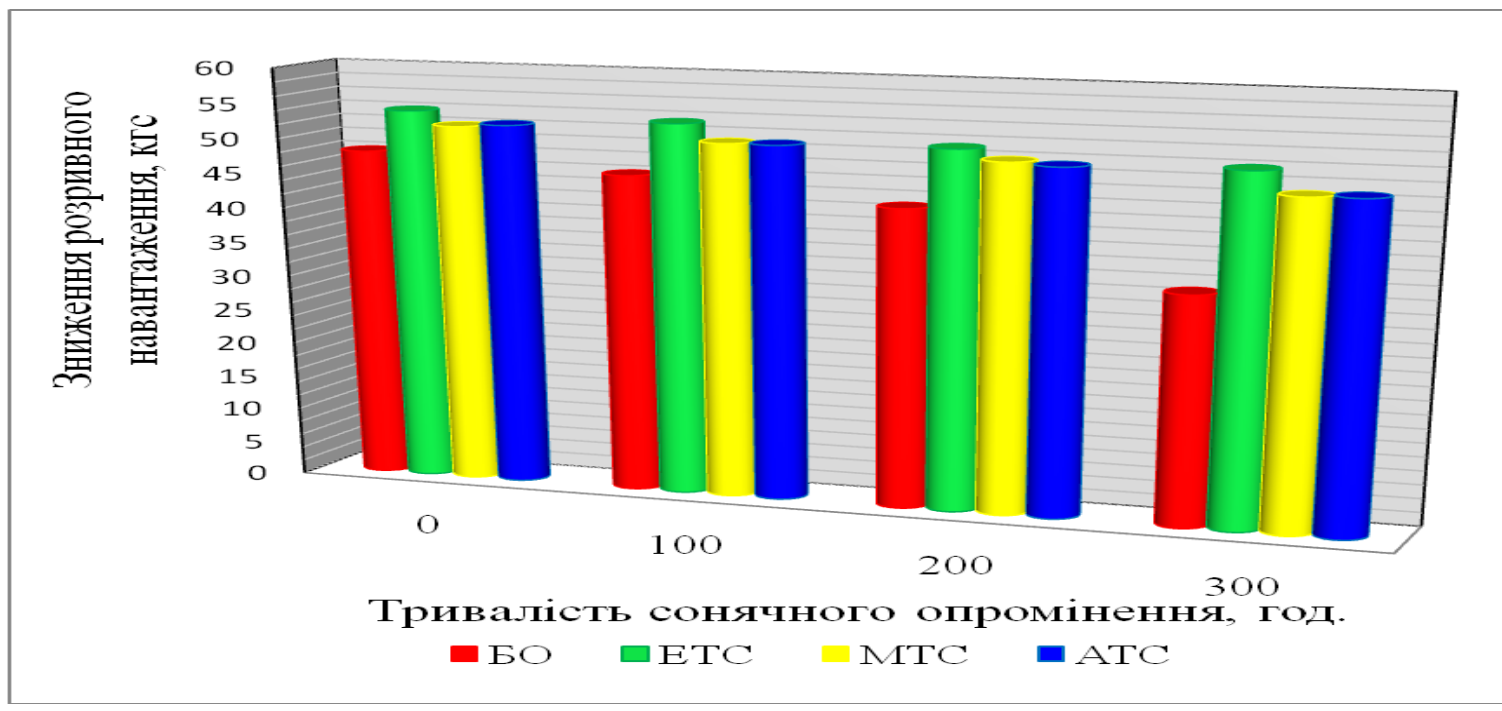

Рис. 2. Зміна розривального навантаження за шириною зразка 1, після 100, 200 і 300 годин сонячного опромінення

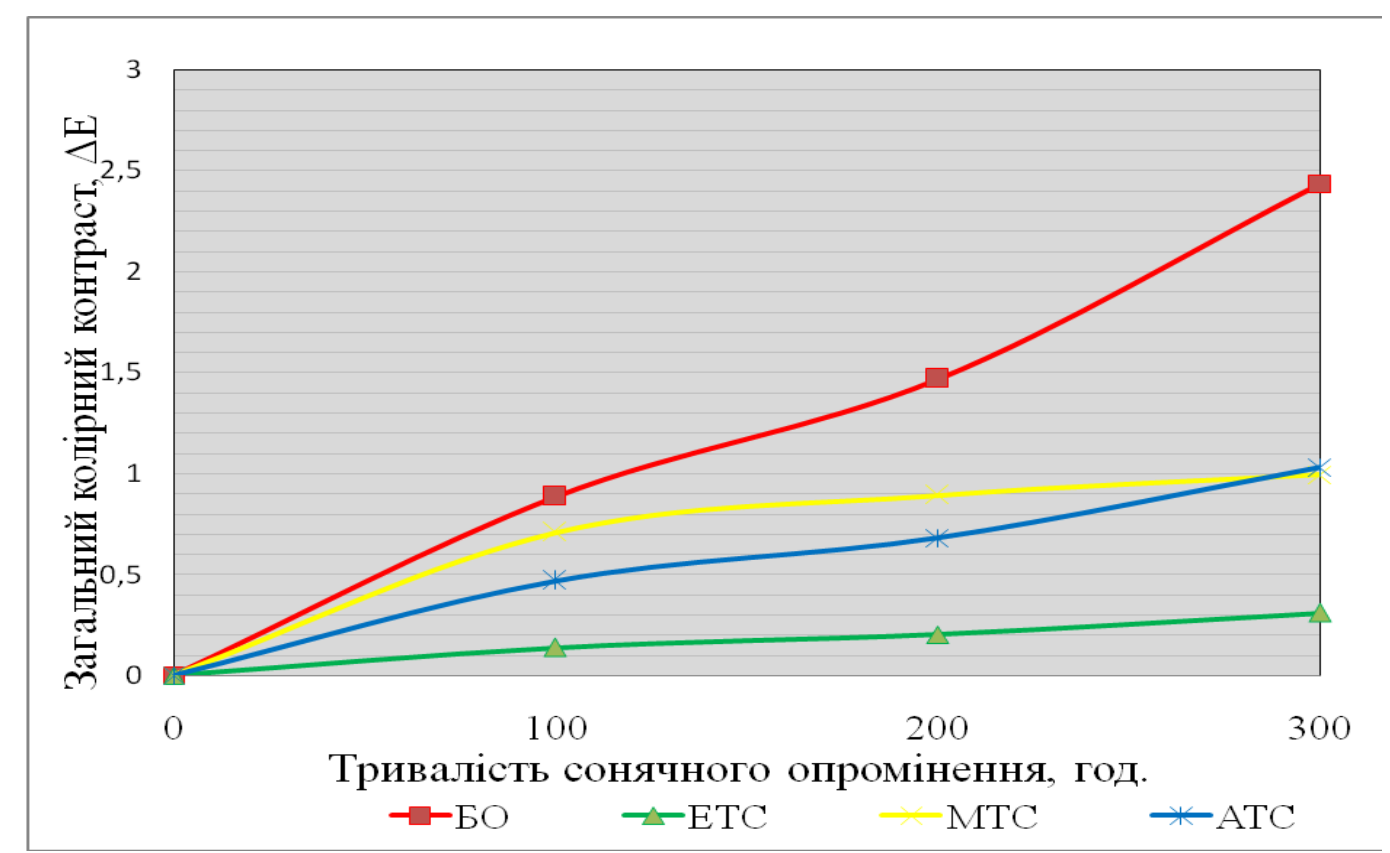

Рис. 3. Залежність світлостійкості забарвлень трикотажу (100\% бавовни - червоний) від тривалості сонячного опромінення

\begin{tabular}{|c|c|c|c|c|}
\hline $\begin{array}{c}\text { № } \\
\text { кривої }\end{array}$ & $\begin{array}{c}\text { Умовні } \\
\text { позначення }\end{array}$ & $\begin{array}{c}\text { Вид } \\
\text { оброблення }\end{array}$ & Рівняння & $\mathrm{R}^{2}$ \\
\hline 1 & - & БО & $\mathrm{Y}=2 \mathrm{E}-0,6 \mathrm{x}^{2}+0,007 \mathrm{x}+0,034$ & 0,99 \\
\hline 2 & & $\mathrm{ETC}$ & $\mathrm{Y}=-9 \mathrm{E}-0,7 \mathrm{x}^{2}+0,001 \mathrm{x}+0,005$ & 0,99 \\
\hline 3 & & $\mathrm{MTC}$ & $\mathrm{Y}=-2 \mathrm{E}-0,5 \mathrm{x}^{2}+0,007 \mathrm{x}+0,022$ & 0,98 \\
\hline 4 & & $\mathrm{ATC}$ & $\mathrm{Y}=-3 \mathrm{E}-0,6 \mathrm{x}^{2}+0,004 \mathrm{x}+0,02$ & 0,99 \\
\hline
\end{tabular}




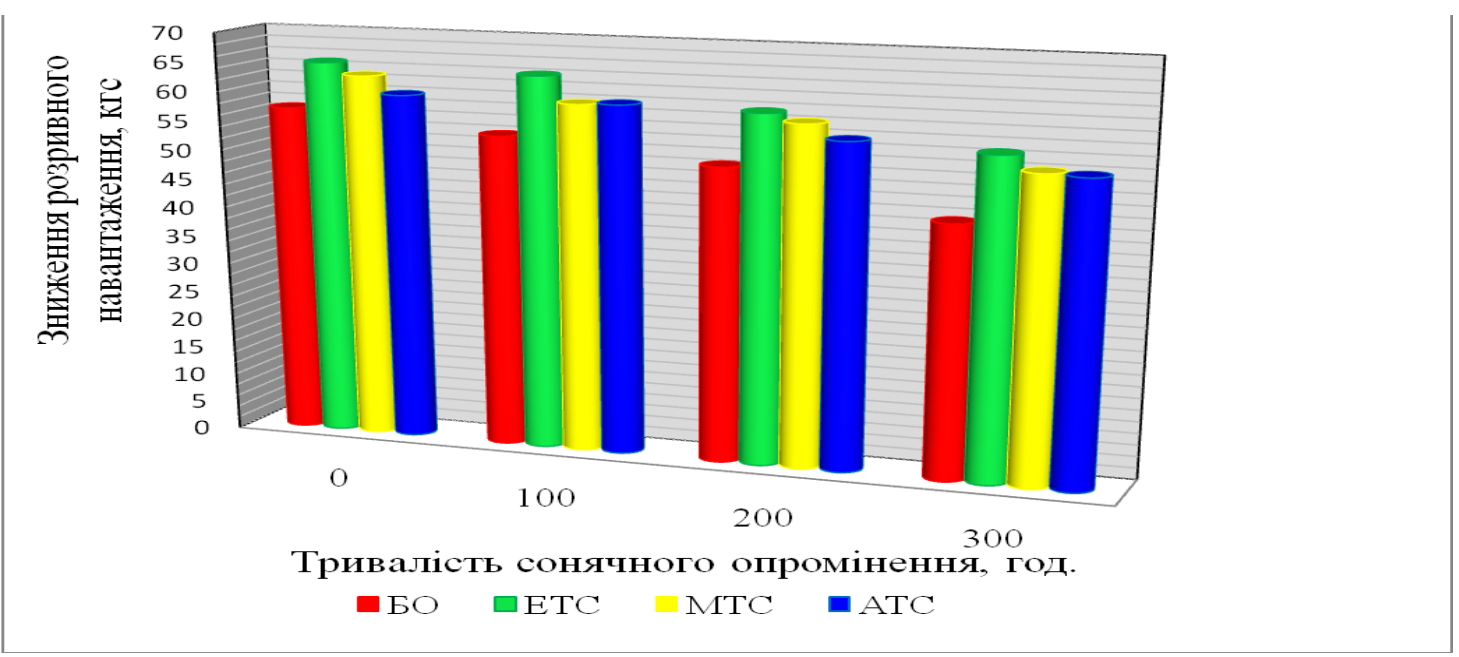

Рис. 4. Зміна розривального навантаження за шириною зразка 2, після 100, 200 і 300 годин сонячного опромінення

На рис. 1-3 видно, що обрані нами тіосульфонатні препарати суттєво гальмують знебарвлення досліджуваних трикотажних полотен вар. 1,2 і 3 в процесі їх сонячної радіації. При цьому кращий світлостабілізуючий ефект, як правило, досягається після оброблення полотен препаратами ЕТС.

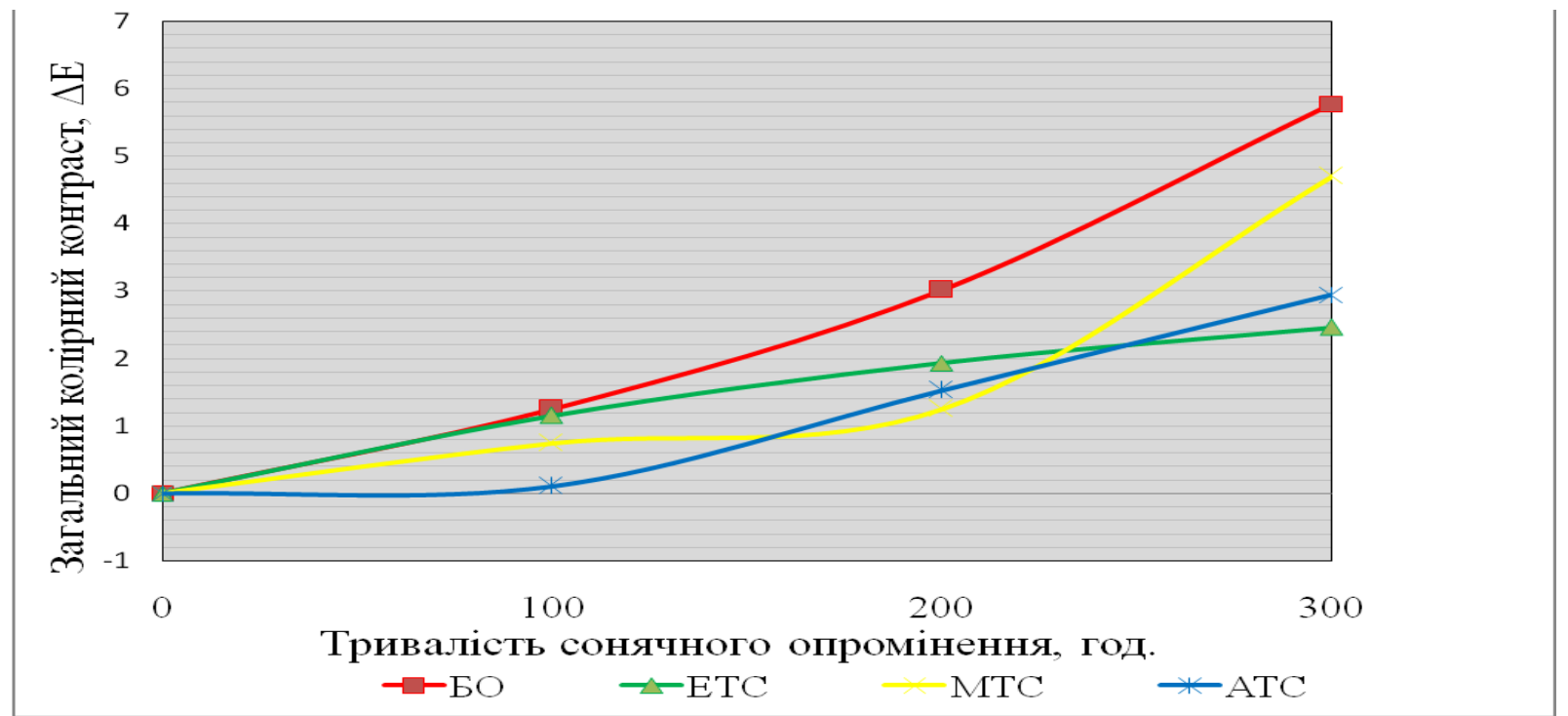

Рис. 5. Залежність світлостійкості забарвлень трикотажу (100 \% бавовни - зелений) від тривалості сонячного опромінення

\begin{tabular}{|c|c|c|c|c|}
\hline $\begin{array}{c}\text { № } \\
\text { кривої }\end{array}$ & $\begin{array}{c}\text { Умовні } \\
\text { позначення }\end{array}$ & $\begin{array}{c}\text { Вид } \\
\text { оброблення }\end{array}$ & Рівняння & $\mathrm{R}^{2}$ \\
\hline 1 & & БО & $\mathrm{Y}=4 \mathrm{E}-0,5 \mathrm{x}^{2}+0,007 \mathrm{x}+0,023$ & 0,999 \\
\hline 2 & & $\mathrm{ETC}$ & $\mathrm{Y}=-2 \mathrm{E}-0,5 \mathrm{x}^{2}+0,012 \mathrm{x}+0,006$ & 0,999 \\
\hline 3 & & $\mathrm{MTC}$ & $\mathrm{Y}=7 \mathrm{E}-0,5 \mathrm{x}^{2}+0,005 \mathrm{x}+0,158$ & 0,96 \\
\hline 4 & $\mathrm{ATC}$ & $\mathrm{Y}=3 \mathrm{E}-0,5 \mathrm{x}^{2}+0,000 \mathrm{x}-0,066$ & 0,98 \\
\hline
\end{tabular}




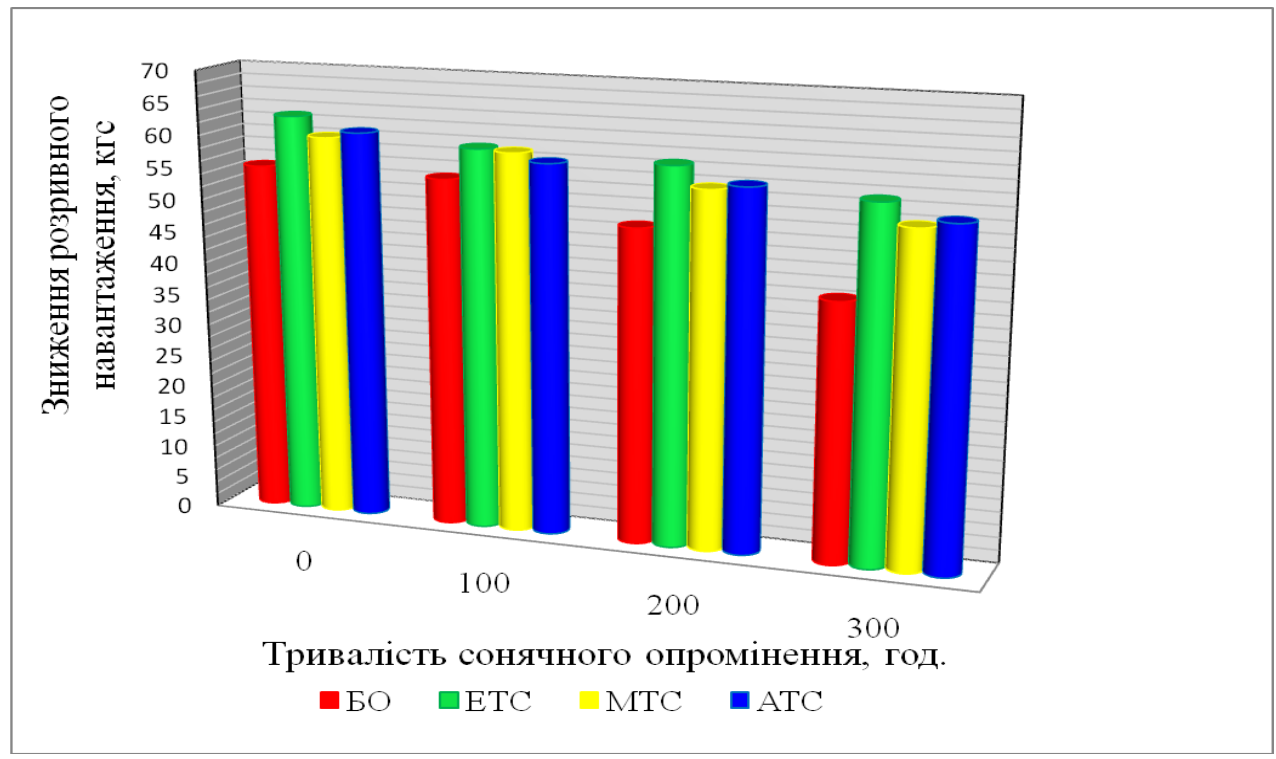

Рис. 6. Зміна розривального навантаження за шириною зразка 3, після 100, 200 і 300 годин сонячного опромінення

3 аналізу даних рисунків 1-6, можна зробити висновок, що обрані нами препарати для антимікробного оброблення забезпечують належну світлостійкість пофарбувань та волокнистої основи досліджуваних тканин. Тому при формуванні заданої світлостійкості, текстильних одягових матеріалів, слід враховувати не тільки їх стійкість до діi різних груп і видів мікроорганізмів, але і вміст волокон, вид барвника і біоцидного обробного препарату в процесі їх мікробіологічного і атмосферного старіння.

Висновки та перспективи подальших досліджень. Вивчена можливість i обгрунтована доцільність використання у вітчизняному текстильному виробництві тіосульфонатних обробних препаратів ЕТС, МТC і АТС для антимікробного оброблення бавовняних білизняних трикотажних полотен літнього асортименту 3 метою їх ефективного захисту від біодеструкції целюлозоруйнуючими патогенними та грунтовими мікроорганізмами.

Встановлено, що в процесі антимікробного оброблення досліджуваних бавовняних трикотажних полотен препаратами ЕTC, MTC i ATC не спостерігається помітних змін їх механічних (розривне навантаження) властивостей, що може погіршити зносостійкість і гігієнічність названих полотен в процесі експлуатації виробів із них.

Не виявлено негативного впливу оброблення препаратами ЕTC, MTC i АТC на зміну колірних характеристик (світлості, насиченості, колірного тону і загального колірного контрасту) і світлостійкості пофарбувань досліджуваних трикотажних полотен кубовими барвниками. 
Встановлено, що антимікробні препарати ЕTC, МТC і ATC здатні ефективно захищати бавовняні білизняні трикотажні полотна літнього асортименту від тривалої дії сонячної радіації.

Основною перевагою тіосульфонатних обробних препаратів $є$ те, що їх використання гарантує одночасне досягнення на трикотажних бавовняних білизняних і одягових полотнах високої атмосферостійкості без погіршення їх механічних властивостей.

\section{Список використаних джерел}

1. Ильичев В.Д. Экологические основы защиты от биоповреждений / В.Д. Ильичев, Б.В. Бочаров, М.В. Горленко - М.: Наука, 1985. - 264c.

2. Галик I.C. Вплив оброблення текстильних матеріалів на формування рівня їх біостійкості та екологічної безпечності / І.С. Галик, Б.Д. Семак // Проблемы легкой и текстильной промышленности Украины. - 2009. - № 1 (15). - С. 16-19.

3. Галик I.C. Шляхи ефективного захисту текстилю від біопошкоджень / I.C. Галик, Б.Д. Семак // Вісник Київського національного університету технологій тп дизайну. -2012. - № 3 - С. 111-117.

4. Галик І.С. Пошук ефективних способів захисту текстилю від дії шкідливих мікроорганізмів / І. С. Галик, Б. Д. Семак, З.М. Семак // Віник Львівської комерційної академії. - Львів: Видавництво Львівської комерційної академії, 2014. - Вип. 14. - С.6-10.

5. Lubenets V. Development of new antimicrobial compositions of thiosulfonate structure / V. Lubenets, O. Karpenko, M. Ponomarenko // Chemistry and Chemical Technology. Vol. 7. №2. P. 119-124.

6. Пахолюк О.В. Використання деяких поліфункціональних обробних препаратів для захисту текстильних целюлозовмісних матеріалів від мікробіологічних пошкоджень / О.В. Пахолюк, Г.О. Пушкар, І.С. Галик, Б.Д. Семак // Вісник Хмельницького національного університету. - 2019. - №1.

7. Пахолюк О.В. Дослідження ефективності біоцидних речовин для оброблення одягових текстильних матеріалів спеціального призначення [текст] / О.В. Пахолюк, В.І. Лубенець, I.А. Мартиросян // Товарознавчий вісник : збірник наукових праць Луцького НТУ. - 2018. - Випуск 11. - С.100-108.

8. Мартиросян І.А. Вплив біоцидного оброблення целюлозовмісних текстильних матеріалів на зміну їх властивостей [текст] /І.А. Мартиросян, О.В. Пахолюк, В.І. Лубенець //Вісник Хмельницького національного університету. - 2018. - № 6. - С. 94-99.

Цель. Целью данной работы является внедрение в ичеллюлозное производство новых типов антимикробных отделочных препаратов для придания одежным хлопчатополиэфирным разнокомпонентным материалам одновременно биостойкости, атмосферостойкости и экологической безопасности. Наиболее востребованным является создание подобных материалов для изготовления изделий бельевого ассортимента, которые непосредственно контактируют с кожей, будучи безопасными для здоровья человека и окружающей среды. Изделия из таких материалов могут быть использованы как в быту, так и в медицинских учреждениях, в пищевой промышленности, в поездах дальнего следования, в армии и т.д. Не менее актуальны проблемы, связанные со снижением затрат на получение таких материалов. Итак, иелью наших исследований является анализ светостойкости окраски и субстрата бельевого хлопкового трикотажа, 
обработанного антимикробными тиосульфонатными отделочными препаратами ЕТС, MTC и ATC.

Методика. При исследованиях использовали предусмотренные действуютими государственными стандартами методы, которые позволяют определить светостойкость окрасок (иветовой тон, светлость, насыщенность, общий иветовой контраст) и разрывные характеристики исследуемых хлопчатобумажных бельевых трикотажных полотен.

Результаты. Изучена возможность и обоснована целесообразность использования в отечественном текстильном и трикотажном производстве тиосульфонатных отделочных препаратов ЕTC, MTC и АTC для антимикробной обработки хлопчатобумажных бельевых трикотажных полотен летнего ассортимента с целью их эффективной защиты от биодеструкции иеллюлозоразрушающими патогенными $и$ грунтовыми микроорганизмами.

Установлено, что в проиессе антимикробной обработки исследуемых хлопчатобумажных трикотажных полотен препаратами ЕTC, MTC u ATC не наблюдается заметных изменений их механических (разрывной нагрузки) свойств, которые могли бы привести к снижению износостойкости и гигиенических показателей названных полотен в процессе их эксплуатациии.

Не выявлено отрицательного влияния обработки препаратами ЕTC, МТС и АТС на изменение цъветовых характеристик (светлости, насыщенности, ияветового тона и общего цветового контраста) и светостойкости окрашивания исследуемых трикотажных полотен кубовыми красителями.

Основным преимуществом тиосульфонатних отделочных препаратов является то, что их использование гарантирует одновременное достижение на трикотажных хлопчатобумажных бельевых и одежных полотнах высокой атмосферостойкости без ухудшения их механических свойств.

Научная новизна. В результате проведенных исследований установлено, что тиосульфонатные антимикробные препараты ЕТС, МТС и АТС способны к эффективной защите хлопчатобумажных бельевых трикотажных полотен летнего ассортимента от длительного воздействия солнечной радиащии.

Практическая значимость. Установлено, что выбранные нами тиосульфонатни препараты ETC, MTC и ATC пригодны не только для эффективной защиты от микробиологической деструкиии, но и от длительного воздействия светопогодьи хлопчатобумажных трикотажных полотен летнего ассортимента (рабочей одежды, спортивного белья).

Ключевые слова: трикотажные полотна, кулирная глядь, антимикробные препараты, светостойкость, светостойкость субстрата, тиосульфонатныле биоцидные nрепарать

Purpose. The purpose of this work is to introduce the new types of antimicrobial preparations to the cellulose production to provide at the same time bio-resistance, weather resistance and environmental safety to cotton, polyester, multi-component materials. The most demanded creation is producing similar materials for the products of linen assortment, which are directly in contact with the skin, safe for human health and environment. Products from such materials can be used both at home and in medical institutions, in the food industry, in trains of long-distance trafficking, in the army, etc.

A lot of attention all over the world is paid for the development of various methods for obtaining and studying the properties of materials with antiseptic attributes. However, despite the large amount of work in this area, many issues are still far from their solution. In particular, the 
actual task is to create environmentally friendly textile materials and knitted cloths with antimicrobial properties, which are stored in wet treatments, washing, light exposure, that is necessary in using underwear in real conditions. The problems associated with reducing the cost to obtain such materials are equally important. Therefore, the purpose of our research is to analyze the light-fastness of paints and the substrate of linen cotton knitted fabrics treated with antimicrobial thiosulfonate preparations of ETS, MTS and ATS.

Method. The methods provided in applicable state standards that determine the lightness of colors (color tone, lightness, saturation, overall color contrast) and the breaking characteristics of the cotton linen fabrics were used in the studies.

Results. The possibility and feasibility of using thiosulonate preparations including ETS, MTS and ATS in the domestic textile and knitwear production for antimicrobial treatment of cotton linen knitted cloths of the summer range for the purpose of their effective protection against biodestruction by cellulose-destroying pathogenic and soil microorganisms are substantiated.

In the process of antimicrobial treatment of the studied cotton knitted fabrics by ETS, MTS and ATS preparations, no noticeable changes in their mechanical (breaking strength) properties are observed, which may worsen the wear resistance and hygienic performance of these fabrics during the operation of products from them.

No negative influence of treatment with ETS, MTS and ATS preparations on the change of color characteristics (lightness, saturation, color tone and general color contrast) and light stability of coloring of studied knitted fabrics by cubic dyes was found.

The main advantage of thiosulfonate treatments is that their use guarantees simultaneous achievement on knitted cotton linen and clothing cloths of high atmospheric resistance without degradation of their mechanical properties.

Scientific novelty. As a result of the research, thiosulfonate antimicrobial preparations including ETS, MTS and ATS are found to able to effectively protect the cotton linen knitted linen of the summer range from prolonged exposure to solar radiation.

Practical significance. The thiosulfonate preparations chosen by us, such as ETS, MTS and ATS, are revealed to suitable not only for effective protection against microbiological destruction, but also from the long-lasting effect of light clothing of cotton knitted linen of summer assortment (working clothes, sportswear).

Key words: knitted cloths, stockinette structure, antimicrobial preparations, light stability, light stability of substrate, thiosulfonate biocidal preparations.

Стаття рекомендована до друку доктором технічних наук, професором Луиького НТУ Байдаковою Л.І. Дата надходження статті в редакиію 11.01.2019 p. 